\title{
Faulty Traditional Practices IN INFANT GARE
}

\section{Prácticas tradicionales defectuosas en el cuidado infantil}

\author{
Soumya Roy \\ Department of Paediatrics, North 24 Parganas District Hospital, Kolkata, India \\ Corresponding:dr.roy85@gmail.com
}

\begin{abstract}
Proper advice regarding home-based care of normal infants is no less important than managing critical diseases. Otherwise parents tend to follow traditional practices running in the family which are often deleterious. Clinicians must also be aware of the faulty traditional practices so that they can actively enquire them in the child's history.

The author enlisted various such faulty traditional practices as experienced by him during his OPD practice in various public and corporate hospitals over a period of five years. Topics relating mainly to the infant age group have been chosen for this article. Relevant search was done on these topics in standard paediatric textbooks, journals, and websites (like WHO, NICE, AAP) to find the validity of these practices as well as the standard recommendations on these topics.

It was found that the standard recommendations often differ from the traditional practices. Detailed text was included from various authentic sources regarding few dubious topics related to home-based infant care.

Clinicians should be aware of the correct recommended methods regarding the day to day homebased infant care. They should counsel the parents accordingly so as to avoid any harm caused by faulty traditional practices and social beliefs.
\end{abstract}

Key words: Bath, Children, Feeding, Infant, Paediatrics, Traditional practice 


\section{Introduction}

More than managing complex diseases and syndromes, parents expect healthcare workers to advise them about how to manage a normal infant properly at home. However incomplete or incorrect or obsolete knowledge about simple chores like "how to bathe an infant" or "what to feed him" leads to the delivery of advice based on personal perceptions and traditional beliefs. Sometimes however the healthcare worker may actively ignore these questions of the new parents, labelling these as 'useless queries'. These parents then have to follow the traditional teachings of the old grand-mothers in the family. Also frequently parents 'hide' (under-report) some points from the doctor because they feel what they did had been perfectly okay and does not need to be reported. Hence the doctors too must be aware of the faulty parental practices carried out traditionally at homes. For example mother may tell that her 4-month old baby, who has presented with diarrhoea, is exclusively breast fed. What she meant is that she does not give formula milk to the baby. What she did not report is that she occasionally feeds him honey. She did not report this because she thought it is perfectly normal to feed honey to an infant and that the doctor will understand it by himself. So doctors need to be aware of such possibility and ask her the leading question that whether she feeds honey or not.

This review article enlists few such topics as experienced by the author during his practice in various public and corporate hospital out-patient departments over a period of five years between 2015 and 2020. It will cover topics mostly related to infants (up to 12 months age).

1. Bathing: The first bath is very important in removing unwanted blood and meconium from the baby's skin. The first bath should be delayed up to 24 hours of birth and never earlier than 6 hours (WHO, 2018). The baby should be immersed as a whole (and not part by part), up to the shoulders, into a tub containing warm water (100.4 Fahrenheit). It is even better to swaddle the neonate in flexed middline position prior to immersion. Sponging appears to be an inferior method. Duration of bathing should be less than 5 minutes (McManus, 2014). Cleansing agents like chlorhexidine should not be added to bathing water, nor should any lotion, medicated wipes, soaps and powders be used in the neonatal period. If very much needed, then a soap of neutral or slightly acidic $\mathrm{pH}$, without fragrance and with added emollient should be used (Sarkar et al, 2010).

2. Cosmetics: Oil massage has no proven benefit (except in low birth weight babies); however excessive oils in hot weather may block sweat pores causing miliria and irritant folliculitis. Traditionally mustard oil is used by many parents, which is allergic to the skin and must be discouraged. Coconut oil is time-tested for use in newborns and may be advised (Sarkar et al, 2010). However as coconut oil solidifies easily during the winter (in contrast to other other oils which never solidifies at home temperature), parents often have the perception that application of coconut oil will lead to baby 'catching a cold'. More often than not, parents are inclined to buy something costlier and 'medicated' than mere coconut oil, which is available in grocery shops and will go on to ignore the doctor's advice; in these cases, commercial preparations of virgin coconut oil may be prescribed. Kajal around eyes, oil in the ears, cleaning ears by sticks and application of powder (in neonates) should be discouraged.

3. Umbilical care: Routine application of any medicine on the umbilical stump and hot fomentation on the stump should be discouraged.

4. Stool: Often parents are worried about 'diarrhoea', 'constipation', colour variability and strenuous passage of stool and urine in the neonate. It must be clarified to them that the neonate normally will pass stool as infrequently as only twice a day in the first 48 hours of life. However failure to pass the first stool within 24 hours of life warrants urgent attention. The voiding frequency then 
increases to up to 6-8 times daily, occurring almost after every feeds. A Turkish study observed that the highest stool frequency occurs on the $15^{\text {th }}$ day with a median frequency of 6 times daily. Up to the age of 5 months, breast fed neonates have higher stool frequency and volume than formula fed babies. At around 4-6 weeks of life, the stool frequency gradually decreases to at least 3 times a day. At 2-3 months of age the stool frequency decreases further, occurring once every few days or even at one week intervals. Duyan Çamurdan et al found that approximately $1 / 4^{\text {th }}(24.8 \%)$ of infants at 2 months of age does not pass stool daily, and around $1 / 4^{\text {th }}(26 \%)$ of these infants passes stool once weekly. The colour of stool is not the adult brown type. It is greenish black in the first 48 hours, followed by yellow yogurt like stools with seedy curds (variously described as 'curd like', 'mashed egg like', 'leafy coloured' etc by the parents), becoming brown at approximately 12 months age. The colour of stool has little significance except for black, red and white stools that must be attended to (Wagner, 2015: Camurdan et al, 2014; Tiwari et al, 2016). Infant should suck each breast 10-15 minutes at a time so as to get both the fore-milk and the hind-milk. An infant who always sucks briefly from both breasts will be getting only lactose-rich foremilk and will present will explosive watery diarrhea (Wagner, 2015). Mothers often complain of distinct vegetable matter like peas or corn in the stool in older infants or toddlers. No digestive enzyme like diastase preparations etc are necessary in these cases as these are due to incomplete chewing (Tiwari et al, 2016).

5. Urine: Parents frequently complain that a neonate cries during urination. The neural control of bladder is not fully developed in neonates; hence when bladder is full they feel pain and starts crying. Distension of bladder as well as increased intra-abdominal pressure due to crying initiate micturition. The neonate stops crying temporarily followed by crying again when his nappy becomes wet with urine. Hence it is important to note whether the neonate is crying 'prior to' or 'during' the passage of urine. The later may warrant attention as a case of dysurea. A normal infant passes urine 6-8 times daily.

6. Sun exposure: Many parents believe that keeping their young infant in direct sunlight has a beneficial effect with respect to increased Vitamin D and strengthening of bones. They need to be counselled that the NICE as well as the AAP statements directly advise that "Babies less than 6 months age should be kept out of direct sunlight." The WHO statement advises to "keep infants of less than 12 months in the shade". These recommendations are in the view of possible damage to eyes, skin and the immature immune system as well as risk of skin cancer. Oral vitamin D supplementation has been recommended instead. (Liacouras,2016; American Academy of Pediatrics, 2019).

7. Feeding: Parents must be made aware of the benefits and methods of successful breast feeding. These have been described in detail in all text books and hence not repeated here. In developing countries, breast feeding should continue through the $2^{\text {nd }}$ year and beyond (World Health Organization, 2009). The mistakes with respect to formula feeding are discussed herein. Many mothers feel that she is not producing enough milk, and practice giving two to three feeds of formula milk along with continued breast feeding. The mistake of this method is that lesser the infant suckles the breast, lesser becomes the breast milk production and greater becomes the dependence of the infant on formula milk. Secondly many mothers tend to mix arbitrary amount of milk powder with arbitrary volume of water, giving the infant either over-concentrated milk (that may lead to gastric distension and overload with protein and salts) or over-diluted milk (that may lead to hunger cry and failure to thrive) (World Health Organization, 2009). The required dilution is $20 \mathrm{cal} /$ ounce (or 75kcal/100ml aka F-75 diet) (World Health Organization, 2009; Michaelsen et al, 2003). Most formula milk brands recommend mixing one level (not heaped) spoon of milk 
powder (spoon provided by the manufacturer) with $30 \mathrm{ml}$ of water. Some companies provide 30 $\mathrm{ml}$ volume cups. Otherwise the 1 ounce mark of a feeding bottle may be used to demonstrate " 30 $\mathrm{ml}$ " to the mother. Also the lids of most syrups have $10 \mathrm{ml}$ volume. So another alternative way is to teach the mother to mix one spoon of milk powder with three such lids of water.

Feeding should be done by spoon or paladai, and not by bottle as the former is easier to sterilise and carries less chance of transmitting infection. The spoon should be filled $3 / 4^{\text {th }}$ with milk. The lower lip is pressed with the spoon, without tilting the spoon. Then the milk is poured inside the mouth on the sides, while the tongue is kept pressed. The spoon is not taken out till the baby swallows the milk. Scraping of the chin or lower cheek with the spoon to collect the spilling milk should be avoided and an extra 2-3 $\mathrm{ml}$ of milk is being fed to adjust for the spilled milk. The baby is burped when half the feed is ingested (Sielski, 2012). Often babies tend to fall asleep after ingesting only a fraction of their feed because the severity of their hunger is alleviated by a few milliliters of milk. In such cases babies should be aroused by providing tactile stimuli to the soles of feet or rubbing the cheeks. Preboiled water should be used to make milk and never mineral water because the later contains lots of salt (Nair PMC, 1994). Volume and interval of feeds should be as per demand. A general guideline is that neonates will feed every 2-3 hours whereas infants (2-6 months) will feed every 3-4 hours (World Health Organization, 2009; Sielski, 2012). Volume of feed is $100-150 \mathrm{ml} / \mathrm{kg}$ body weight divided into 8-12 feeds for neonates and 6-8 feeds for infants. Babies must be woken up from sleep at night for the stipulated feed. The above formula should serve as a guideline to evaluate whether a baby is being under-fed in case of an infant presenting with inconsolable cry or failure to thrive. Again, the formula may be used to assess overfeeding in a baby presenting with persistent vomiting.

Cow or goat milk (unmodified) is contraindicated up to 9 months of age, or if feasible up to 1 year due to the high renal solute load, increased gastrointestinal bleeding and low iron content. Wherever breast feeding is not possible and formula milk is not affordable, there modified milk (130 ml of cow/goat milk diluted with $70 \mathrm{ml}$ of water and 1 teaspoonful of sugar added) should be offered to the infant. Parents are to be cautioned against use of skimmed milk, condensed milk, milk substitutes and dairy whiteners (used for making tea). Honey, often given as a home remedy for cough, is contraindicated in children under 12 months age due to possibility of caries and botulism. Tea (reduces iron absorption by $62 \%$ ), coffee, extra sugar and sugary drinks (causes caries) and vegetarian diet should not be given to young children. Red meat, poultry, fish, liver and egg can be introduced after as early as 6 months (World Health Organization, 2009; Family Health Service, Department of Health, The Government of the Hong Kong Special Administrative Region, 2005). Excessive fruit juice (which are low energy drinks) consumption causes diarrhea as well as loss of appetite for other foods leading to malnutrition and should be limited to less than $180 \mathrm{ml}$ daily. Between 6-24 months, meals, including milk-only feeds, other foods, and combinations of milk feeds and other foods, should be provided four or five times per day. Above 9 months unmodified cow's milk can be given but the misconception that "drinking raw cow's milk straight milked from the udder is the best" has to be changed and only pasteurized or boiled milk should be given. During an episode of diarrhea, one has to be careful with cow's milk because the high protein and mineral content present in cow's milk produces a high renal solute load, resulting in a negative water balance and precipitating a severe dehydration (Family Health Service, Department of Health, The Government of the Hong Kong Special Administrative Region, 2005; World Health Organization, 2005; Ziegler EE, 2007). Frequently complementary feeding is being delayed due to religious or cultural reasons because the first day of eating solid food has to be celebrated on a particular auspicious day (Annaprashana, 2019). Complementary 
feeding should never be delayed beyond 6 months and can be started even at 4 months (World Health Organization, 2009). In view of the small stomach size of infants, more calories are to be included in smaller volumes of foods (solid foods) by adding sugar, jiggery, ghee, butter and oil to the food. Self feeding should be encouraged. GYOR (green, yellow, orange, red) vegetables should be emphasized upon and "magic" health drinks, junk foods, artificial, packaged, tinned foods should be discouraged over home foods (Schwartz et al, 2017).

8. Intestinal worms: There is a common misconception among parents that bruxism (teeth grinding) and eating too much sweet food are associated with intestinal worms (Tehrani, 2013). However many parents who are agitated with uncontrolled hookworms in their children are not aware of the importance of wearing shoes, washing hands before eating and keeping nails short in preventing hookworms. Also there is no role of laxative or vitamins after a prescription of albdendazole. It is also a misconception that antihelminthics can be only given during cooler weather conditions like monsoon and winter.

9. Diarrhoea: Parents need to be counseled that the commonest etiology of childhood diarrhea (rotavirus) may take over an week (4-8days) to heal and that there is no need to panic. In acute diarrheas (diarrhea $<1$ week), after the hydration status has been taken care of, child should be straightaway given full strength milk and his usual solid foods. Milk should not be extra diluted nor should any food (except fruit juice and carbonated drinks) be restricted (Tehrani et al, 2013). Commercial preparations of ORS should be strongly insisted upon. Home preparations of ORS made of arbitrary amount of water, sugar, table salt and lemon juice lack the specified osmolarity and potassium supplementation. Hence home ORS must be discouraged (unless commercial ORS is unavailable) as these can worsen diarrhea due to possible hyperosmolarity and lead to abdominal distension due to uncorrected hypokalaemia. Diapers are better avoided in diarrhea because these interfere in the early recognition of reduced urine output. Intermittent loose stools in otherwise healthy children (between 1-3 years age) occurring during the day and not overnight may be attributed to toddler's diarrhea. No treatment is needed except restricting excessive carbohydratecontaining beverages and fruit juice (Tiwari et al, 2016). Use of ORS for unlicensed indications like short-term anorexia in febrile children is common and need to be discouraged.

10. Constipation: Some nursing infants might normally pass any stool for 1-2 weeks (Tiwari et al, 2016) and traditional practices to induce defecation like insertion of betel leaf stalk soaked in coconut oil through anus, though not recommended in any standard guideline, was found to be harmless in one study (National Institute of Health and Care Excellence, 2009). Simple delay in passage of stools by a few days should not prompt the use of laxatives and functional constipation should be treated only if the ROME III criteria are satisfied (Mandal \& Roy, 2018). Parents should be counseled that laxative treatment should continue for at least 3 months even though constipation seem to have resolved and any sudden discontinuation will lead to rebound constipation (Mandal \& Roy, 2018).

11. Fever: Monitoring of fever at home by hand instead of using a thermometer very often leads the parents to provide an incorrect description of their child's illness to the doctor. The wrong history leads to unnecessary investigations and antibiotics. Oral thermometer, tepid sponging and undressing/over-wrapping the child during fever are not recommemded. The aim of giving paracetamol is solely to reduce the agitation of the febrile child and has no role in prevention of febrile convulsion (Poddar, 2016). Fever in neonates must be seen by a paediatrician and parents must be counseled not to observe a febrile neonate at home by giving paracetamol drops on their own. 
12. Cough: Parents frequently believe pressurized meter dose inhaler with spacer and face mask $(\mathrm{pMDI}+\mathrm{S})$, as applicable to be expensive, habit forming, addictive and last resort medicine not suitable for young children. Long term steroid inhalation even when the child is clinically well is also looked down upon as unnecessary (National Institute of Health and Care Excellence, 2019). Parents need to be properly counseled in this regard.

It is surprising how many parents overtly prefer short term use of nebulizers compared to pMDI+S probably because of their psychological satisfaction with huge noise and cloud of smoke produced by the nebulizer. The use of self-prescribed salbutamol nebulisation without consulting a paediatrician, either at home or at a pharmacy shop, for cough with or without respiratory distress, is on the rise. However the dangers of unsupervised home based nebulizers are manifold. Firstly, in acute respiratory infections, temporary relief of dyspneic symptoms often results in a delay in bringing the child to a doctor's attention and thereby delays the start of antibiotics, where needed. Secondly, in cases of asthma, the prompt relief of symptoms by salbutamol nebulizer at home often leads to reduced compliance to other oral medications of asthma as well as delays the regular follow up needed for asthmatics. These factors have increased the mortality and morbidity according to several studies (Ghosh, 2004). Besides the amount of aerosolized drug reaching the lungs is lesser for nebulizers than pMDI $+\mathrm{S}(<10 \%$ vs $10-40 \%)$. Several studies have confirmed that $\mathrm{pMDI}+\mathrm{S}$ use leads to lesser hospital rate, greater reduction in validated clinical severity score and faster symptom resolution in a child with bronchospasm compared to nebulizers and are more effective than nebulizers even in emergency settings (Butz et al, 2006).

13. Studies show that $90 \%$ respondents regularly clean their children's ear wax themselves. A higher incidence of cerumen has been seen to occur in ears cleaned by cotton tipped swabs. Patients should be counseled not to insert any foreign objects into the ear canal, as these objects can cause injuries or worsen cerumen impaction by pushing cerumen deeper into the canal (Smith \& Goldman, 2012). Whom to treat for ear wax and whom not to treat is beyond the scope of this article (Smith \& Goldman, 2012).

14. Teeth: The first tooth erupts at 4- and 15-months age. If first tooth does not erupt by 18 months, child should be referred to a dentist. Fluoridated toothpaste should not be used before 2 years age. The gums of a very small infant should be wiped by a soft wash-cloth or soft tooth-brush even teeth have not erupted. Brushing should be done twice daily and up to 2 years, parents should perform the brushing activity (American Academy of Pediatrics, 2009)

15. Food fussiness: Regular meal timings, pleasant ambience, offering an wide variety of food, showing that the parents too enjoy the food, offering small serving at a time, avoiding force feeding, appreciation for good eating, restriction of grazing diet in between major meals, avoiding water before or during food, avoiding distraction strategies like TV or mobile are to be tried in children with food fussiness (Agarwal et al, 2009).

16. Thumb sucking is a normal behavior in infants, peaking at 18-21 months and should be ignored until 4 years age (Agarwal et al, 2009).

17. SIDS (sudden infant death syndrome): This refers to the sudden and unexpected death of an infant under 12 months of age, with onset of the lethal episode apparently occurring during normal sleep, which remains unexplained after a thorough investigation including performance of a complete post- mortem examination and review of the circumstances of death and the clinical history (The Royal College of Pathologists, 2016) in USA, SIDS is the commonest cause of postneonatal (1 month to 1 year age) mortality and the $3^{\text {rd }}$ commonest cause of infant mortality. It 
may be prevented by continuing breast feeding, providing pacifier to baby, adequate vaccination, avoiding prone and side sleep position, tobacco smoke exposure, soft bedding, bed sharing with parents, heat and cold stress (hence over-wrapping or under-wrapping avoided) (Hunt et al, 2016).

18. Surface area of head in neonates is large compared to their body and hence cap is very important to prevent cold stress. Parents should compare the abdominal temperature with that of hands and feet; if the later is cooler, child is going to cold stress.

19. Reflux (regurgitation/posseting) of small amount of feed milk within a small time after feeding, that occurs without much force, usually by the angle of the mouth occurs in $40 \%$ infants and up to 6 times daily. It resolves spontaneously by 1 year and must be differentiated from vomiting, which may be forceful, may occur much later than last feed and requires treatment. Parental anxiety should be alleviated and antiemetics avoided in reflux (National Institute of Health and Care Excellence, 2015).

20. Neonatal breast enlargement is normal and parents should be warned not to try to "press milk out".

21. Head shaving in infants is often a religious custom but may lead to meningitis.

22. If a baby has become accustomed to using a pacifier (dummy) while sleeping, it should not be stopped suddenly during the first 26 weeks (National Institute of Health and Care Excellence, 2015b)

23. Several authors opined that gripe water "may cause harm" and must hence better be avoided (Johnson et al, 2015).

24. Contrary to the popular belief, a baby born by caesarean section is not weaker than that borne by vaginal delivery.

25. The parental perception that "the infant is having excessive gas" just because he is passing flatus is wrong and does not need treatment with digestive enzymes.

26. Massaging of infants leads to improved weight gain, growth, pain tolerance and sleep as well as decreased hyperbilirubinemia in infants (Juneau et al, 2015).

27. In India, weight of child is being measured regularly during vaccination as well as during visits to most private doctor clinics. Height is often measured during school health check-up. But most parents do not bother to remember or retain those parameters which are invaluable to monitor the growth velocity and health factors of the child in future. Educated parents may even be encouraged to use mobile apps to self-monitor their child's growth (Zuventus Healthcare, 2017). Frequently parents are falsely worried that their child "does not eat properly". Over the counter vitamins, appetite stimulants, "magic" health drinks, enzymes (diastase) etc are to discouraged and Z-score of the child's growth be displayed to the parents to re-assure them. And although they are falsely worried about their children being underweight, most parents ignore, or are in fact happy, when their children are overweight.

28. Infants sleep for 12.8 hours and toddlers sleep for 11.9 hours per day. Infants $<2$ months wake from 0 to 3-4 times per night while children between 1-2 years wake from 0 to 2-3 times per night (Galland et al, 2012).

29. There is a significant association between the frequency of touch-screen use and sleep quantity (reduced total duration, with reduced duration of night-time and increased daytime sleep), and longer sleep onset (time taken to fall asleep) in children as young as 6-36 months. Every additional 
hour of tablet use was associated with 15.6 minutes less total sleep on average (Cheung et al, 2017). The American Academy of Pediatrics recommends not to use screen media (mobile, TV, tablet) up to 18 months of age. Even between 2-5 years the recommended screen time is only one hour. Parents should co-view with their children and explain what they are seeing (American Academy of Pediatrics, 2016).

30. Frequently parents (and health care workers) continue to postpone the vaccination of a child because he is suffering from one or the other trivial illnesses on the dates of vaccination; the procrastination continues till the vaccine is entirely missed (Centres for Disease Control and Prevention, 2019). It must be clarified that allergy, asthma, minor illness like respiratory tract infections or diarrhea with temperature $<38.5 \AA \mathrm{C}$, chronic diseases of heart, lung, kidney, liver, history of Guillain-Barré syndrome, stable neurological conditions (cerebral palsy or Down's syndrome), malnutrition, prematurity or low birth weight, HIV (without AIDS), recent or imminent surgery, antibiotic treatment, family history of convulsion and family history of adverse effects following immunization are not contraindications to vaccination (Centres for Disease Control and Prevention, 2019; World Health Organization, 2004). Often parents do not bother to immunize their child against certain diseases which are unnecessary economic expense according to their perception (For example, mumps measles rubella and varicella are often perceived as "common and mild diseases"). They need proper counseling.

\section{Declaration of conflict of interest}

None

\section{Status of ethical clearance for the study}

Not applicable

\section{References}

Agarwal R, Jain V, Sankhyan N. Development. In: Ghai OP, Paul VK, Bagga A. Essential Paediatrics, $7^{\text {th }}$ ed. New Delhi. CBS Publishers \& Distributors Pvt Ltd. 2009; page 58-59.

American Academy of Pediatrics. Sun Safety and Protection Tips from the American Academy of Pediatrics. Published: 2019. Available at: https://www.aap.org/en-us/about-the-aap/aap-pressroom/news-features-and-safety-tips/Pages/Sun-Safety-and-Protection.aspx. Date of access: 12 Jan 2020.

American Academy of Pediatrics. A Pediatric Guide to Children's Oral Health. Elk Grove Village, IL: American Academy of Pediatrics; 2009. Available at: https://www.aap.org/en-us/advocacy-andpolicy/aap-health-initiatives/Oral-Health/Documents/OralHealthFCpagesF2_2_1.pdf. Date of acccess: 12 Jan 2020.

American Academy of Pediatrics. American Academy of Pediatrics Announces New Recommendations for Children's Media Use. Published: 10 Feb 2016. Available at: https://www.aap.org/en-us/ about-the-aap/aap-press-room/Pages/American-Academy-of-Pediatrics-Announces-NewRecommendations-for-Childrens-Media-Use.aspx. Date of acccess: 12 Jan 2020. 
Annaprashana. Last edited: 16 Oct 2019. Available at: https://en.wikipedia.org/wiki/Annaprashana. Date of acccess: 12 Jan 2020.

Butz AM, RN, Tsoukleris MG, Donithan M et al. Effectiveness of Nebulizer Use-Targeted Asthma Education on Underserved Children with Asthma. Arch Pediatr Adolesc Med. 2006 June; 160(6): 622-628. https://dx.doi.org/10.1001\%2Farchpedi.160.6.622

Camurdan AD, Beyazova U, Ozkan S, Tunc VT. Defecation patterns of the infants mainly breastfed from birth till the 12th month: Prospective cohort study. Turk J Gastroenterol 2014; 25 (Suppl.-1): 1-5 https://doi.org/10.5152/tjg.2014.5218

Centres for Disease Control and Prevention. Contraindications and Precautions. In: Vaccine Recommendations and Guidelines of the ACIP. Updated: 15 Nov 2019. Available at: https://www. cdc.gov/vaccines/hcp/acip-recs/general-recs/contraindications.html\#ref-37. Date of acccess: 12 Jan 2020 .

Cheung CHM, Bedford R, Saez De Urabain IR, Karmiloff-Smith A, Smith TJ. Daily touchscreen use in infants and toddlers is associated with reduced sleep and delayed sleep onset. Sci Rep. 2017 Apr 13;7. 46104. https://doi.org/10.1038/srep46104

Family Health Service, Department of Health, The Government of the Hong Kong Special Administrative Region. Guide to bottle feeding: How to prepare infant formula and feed your baby safely. Updated: 08 Jan 2020. Available at: https://www.fhs.gov.hk/english/health_info/ child/12146.html. Date of acccess: 12 Jan 2020.

Galland BC, Taylor BJ, Elder DE, Herbison P. Normal sleep patterns in infants and children: a systematic review of observational studies. Sleep Med Rev. 2012 Jun;16(3):213-22.

Ghosh G. Optimal Care for Asthmatic Children-Do We Need Special Clinics? Indian Pediatr 2004; 41:907-911 https://pubmed.ncbi.nlm.nih.gov/15475632/

Hunt GE, Hauck FR. Sudden Infant Death Syndrome. In: Kliegman RM, Stanton BF, St Geme JW III, Schor NF: Nelson Textbook Of pediatrics. $20^{\text {th }}$ ed. Canada: Elsevier; 2016. pg 1999-2001

Johnson JD, Cocker K, Chang E. Infantile Colic: Recognition and Treatment. Am Fam Physician. 2015 Oct 1;92(7):577-582.

Juneau AL, Aita M, Héon M. Review and Critical Analysis of Massage Studies for Term and Preterm Infants. Neonatal Netw. 2015;34(3):165-77.

Liacouras CA. Normal digestive tract phenomena. In: Kliegman RM, Stanton BF, St Geme JW III, Schor NF: Nelson Textbook Of pediatrics. 20 ${ }^{\text {th }}$ ed. Canada: Elsevier; 2016. Pg 1757. https://www. us.elsevierhealth.com/nelson-textbook-of-pediatrics-2-volume-set-9780323529501.html

Nair PMC, Narang A, Mahajan R, Arora U. Spoon Feeds-An Alternative to Bottle Feeding. Indian Pediatr. 1994 Dec;31: 1566-1567. https://pubmed.ncbi.nlm.nih.gov/8617570/

National Institute of Health and Care Excellence. Reflux, regurgitation and heartburn in babies, children and young people. Published: 14 January 2015. Available at: https://www.nice.org.uk/ guidance/ng1/resources/reflux-regurgitation-and-heartburn-in-babies-children-and-youngpeople-pdf-555907525. Date of access: 12 Jan 2020.

National Institute of Health and Care Excellence. Postnatal care up to 8 weeks after birth. Clinical guideline [CG37]. Updated: Feb 2015. Available at: https://www.nice.org.uk/guidance/cg37/ chapter/1-Recommendations. Date of access: 12 Jan 2020. 
National Institute for Health and Care Excellence. Sunlight exposure: risks and benefits. NICE guideline. Published: 9 February 2016. Available at: https://www.nice.org.uk/guidance/ng34/ resources/sunlight-exposure-risks-and-benefits-1837392363205. Date of access: 12 Jan 2020.

National Institute of Health and Care Excellence. Diarrhoea and vomiting caused by gastroenteritis in under 5s: diagnosis and management. Clinical guideline [GG84]. Published date: April 2009. Available at: https://www.nice.org.uk/guidance/cg84/chapter/Key-priorities-forimplementation. Date of acccess: 12 Jan 2020.

Mandal K, Roy A. Rectal stimulation to relieve constipation in infants: is it safe? Int J Contemp Pediatr. 2018 Sep;5(5):1888-1891. https://dx.doi.org/10.18203/2349-3291.ijcp20183525

McManus Kuller J. Update on Newborn Bathing. Medscape 2014. Available at: https://www. medscape.com/viewarticle/838253_3 Date of access: 12 Jan 2020.

Michaelsen KF, Weaver L, Branca F, Robertson A. Breast Feeding and alternatives. In: Feeding and nutrition of infants and young children. World Health Organization regional publications. Updated reprint: 2003. Available at: http://www.euro.who.int/_data/assets/pdf_file/0004/98302/ WS_115_2000FE.pdf. Date of access: 12 Jan 2020.

National Institute of Health and Care Excellence. Fever in under 5s: assessment and initial management. NICE guideline [NG143]. Published date: November 2019. Available at: https:// www.nice.org.uk/guidance/ng143/chapter/Recommendations. Date of access: 12 Jan 2020.

Poddar U. Approach to Constipation in Children. Indian Pediatr. 2016 Aug 15;53: 319-327. https:// doi.org/10.1007/s13312-016-0845-9

Sarkar R, Basu S, Agrawal RK, Gupta P. Skin Care for the Newborn. Indian Pediatr. 2010;47: 593598 https://doi.org/10.1007/s13312-010-0132-0

Sielski LA, McKnee-Garrett TM. Care of the Well Newborn. In: Cloherty JP, Eichenwald EC, Hansen AR, Stark AR. Manual of Neonatal Care. $7^{\text {th }}$ Ed. Philadelphia: Wolters Kluwer (India) Pvt Ltd;2012. pg. 107. http://www.ypeda.com/attachments/article/150/manual\%20of $\% 20$ neonatal $\% 20$ care $\% 207$ th.pdf

Smith C, Goldman RD. Nebulizers versus pressurized metered-dose inhalers in preschool children with wheezing. Can Fam Physician. 2012;58(5):528-530. http://www.ncbi.nlm.nih.gov/pmc/ articles/pmc3352788/

Schwartz SR, Magit AE, Rosenfeld RM et al. Glinical Practice Guideline (Update): Earwax (Cerumen Impaction). Otolaryngology- Head and Neck Surgery 2017, Vol. 156(1S) S1- S29

Tiwari S, Bharadva K, Yadav B et al. Infant and Young Child Feeding Guidelines, 2016. Indian Pediatr. 2016 Aug 15;53: 703-713.

Tehrani MH, Sadri L, Mowlavi G. Intestinal Parasites and Bruxism in Ghildren. Iran J Public Health. 2013 Oct; 42(10): 1199.

The Royal College of Pathologists. Sudden unexpected death in infancy and childhood. $2^{\text {nd }}$ Edition. Nov 2016. Available at: https://www.rcpath.org/uploads/assets/874ae50e-c754-4933995a804e0ef728a4/Sudden-unexpected-death-in-infancy-and-childhood-2e.pdf. Date of acccess: 12 Jan 2020.

Thermal management. In: Agarwal R, Deorari A, Paul VK. AIIMS protocols in neonatology. $1^{\text {st }}$ ed. New Delhi. CBS Publishers \& Distributors Pvt Ltd. 2009; page 16. 
WHO recommendation on bathing and other immediate postnatal care of the newborn. 17 February 2018. Available at: https://extranet.who.int/rhl/topics/newborn-health/care-newborn-infant/ who-recommendation-bathing-and-other-immediate-postnatal-care-newborn. Date of access: 12 Jan 2020.

Wagner CL. Counseling the Breastfeeding Mother. Medscape. Updated: Feb 05, 2015. Available at: https://emedicine.medscape.com/article/979458-overview\#showall. Date of access: 12 Jan 2020.

World Health Organization. Protecting children from ultraviolet radiation. Archived: 11 December 2009. Available at: https://www.who.int/uv/resources/archives/fs261/en/. Date of access: 12 Jan 2020.

World Health Organization. Guiding Principles for Feeding Non-Breastfed Children 6-24 Months of Age. Published: 2005. Available at: https://apps.who.int/iris/bitstream/ handle/10665/43281/9241593431.pdf. Date of access: 12 Jan 2020.

World Health Organization. Department of Immunization, Vaccines and Biologicals. Chapter 14, Module 2. Summary. In: World Health Organization: Immunization in Practice: A Practical Guide for Health Staff. China: Sunfung Offset Binding Co Limited; May 2004: page 25.

Ziegler EE. Adverse effects of cow's milk in infants. Nestle Nutr Workshop Ser Pediatr Program. 2007;60:185-199.

Zuventus Healthcare. IAP Growth Chart Application. Updated Jan 16, 2017. Available at (Playstore for android mobiles): https://play.google.com/store/apps/details?id=com.mindspacetech. iapgrowthcharts. Date of access: 12 Jan 2020.

\section{RESUMEN}

$\mathrm{El}$ asesoramiento adecuado sobre la atención domiciliaria de los bebés normales no es menos importante que el manejo de enfermedades críticas. De lo contrario, los padres tienden a seguir las prácticas tradicionales de la familia que a menudo son perjudiciales. Los médicos también deben ser conscientes de las prácticas tradicionales defectuosas para poder investigarlas activamente en la historia del niño.

El autor reclutó varias prácticas tradicionales defectuosas que experimentó durante su práctica en OPD en varios hospitales públicos y corporativos durante un período de cinco años. Para este artículo se han elegido temas relacionados principalmente con el grupo de edad infantil. Se realizaron búsquedas relevantes sobre estos temas en libros de texto, revistas y sitios web estándar de pediatría (como OMS, NICE, AAP) para encontrar la validez de estas prácticas, así como las recomendaciones estándar sobre estos temas.

Se encontró que las recomendaciones estándar a menudo difieren de las prácticas tradicionales. Se incluyó texto detallado de varias fuentes auténticas con respecto a algunos temas dudosos relacionados con el cuidado infantil en el hogar.

Los médicos deben conocer los métodos correctos recomendados con respecto al cuidado infantil diario en el hogar. Deben asesorar a los padres en consecuencia para evitar cualquier daño causado por prácticas tradicionales y creencias sociales defectuosas.

Palabras clave: Baño; niños; alimentación; lactante; pediatría; práctica tradicional. 